\title{
Theoretical Conceptual Assembly for the Analysis of Sugarcane Agroecosystems in the Central Gulf of Mexico: An Eclectic Model
}

\author{
Itzel Galaviz-Villa ${ }^{1}$, Cesáreo Landeros-Sánchez ${ }^{2}$, Ma. del Refugio Castañeda-Chávez ${ }^{1}$ \& \\ Fabiola Lango-Reynoso ${ }^{1}$ \\ ${ }^{1}$ Instituto Tecnológico de Boca del Río, División de Estudios de Posgrado e Investigación, Km.12 Carretera \\ Veracruz-Córdoba, Boca del Río, Ver, México \\ ${ }^{2}$ Colegio de Postgraduados, Campus Veracruz, México \\ Correspondence: Itzel Galaviz-Villa, Instituto Tecnológico de Boca del Río, División de Estudios de Posgrado e \\ Investigación, Km.12 Carretera Veracruz-Córdoba, Boca del Río, Ver, México. Tel: 1-229-986-0189 Ext. 113. \\ E-mail: itzelgalaviz.itboca@gmail.com
}

Received: August 9, 2012 Accepted: August 20, 2012 Online Published: November 15, 2012

doi:10.5539/jas.v4n12p214 URL: http://dx.doi.org/10.5539/jas.v4n12p214

\begin{abstract}
Our analytical model for agroecosystems having sugarcane production (SAEs) in the central Gulf of Mexico is based on several philosophical currents for a realistic analysis of a specific time and location, according to the context and focus of the currents. Given the premise that the search for complex knowledge is a product of continuous learning, the model is partially founded on the theory of complexity. Traditionally, when adequate procedures are used to undertake any problem of investigation in its totality, it is called a dialectical method; in contrast, another starting point is systemic thought. With the use of these theoretical-philosophical tools, it is possible to construct a model that promotes communication among actors, between sugarcane producers and institutions, so they may jointly design technological products and services according to the level of production and the needs of each grower.
\end{abstract}

Keywords: agroecosystems analytical model, theoretical-philosophical currents, scientific investigation

\section{Introduction}

In this report, a brief discussion on the design and application of an analytical model for agroecosystems having sugarcane production is provided. Included are some theoretical-philosophical elements from schools of thought such as dialectic and historic materialism (Marx and Engels), human complexity (Edgar Morin), complex (Rolando García) and systemic thought (Enrique Herrscher), and structural functionalism (Manuel Parra). Yet, even when these schools of thought differ in some of their principles, each one contributes important elements that help to form and explain the capacities and limits of the model to make it more inclusive.

\section{Analytical Model Objective}

Our objective was to study a section of reality for a specific location in space and time along the border of knowledge with adequate tools and to explain the results according to the context and foci of the different schools of thought.

\section{Philosophy and Organization}

Our analytical model is based on several philosophical schools of thought, one of them the inductive empirical current. Coincident with this is the idea that experience is the origin of knowledge, but it does not have limits (Pérez-Tamayo, 1998); the object of study is classical (observable, measurable, normative, jurist, etc.) and has been for the last 450 years. In this manner, we consider the observation of measurable effects from the producer's experience to explain the type of management conducted in the SAEs. These effects can be considered sources of knowledge for the design of new strategies and technological products and services to improve the conservation and wise use of the environment.

Coinciding with the empirical current, a positivist point of view is employed, recognizing the scientific knowledge generated from theories and application of the scientific method (Pérez-Tamayo, 1998). To obtain a more extensive and integral vision that integrates the study of SAEs (as individual systems and as parts of larger 
systems), we return to a holistic philosophy, which emphasizes the integration of events with their overall context (the whole is greater than the sum of its parts). Holism refers to a way of seeing things in their entirety. In the opinion of a group of Frankfurt theoreticians, to study the whole is to study nothing; with a holistic focus only a fraction of time and space is studied. As such, we learn to appreciate interactions as well as their characteristics and regulatory processes, things that are not perceived if the individual parts are studied independently (Hurtado, 2000). It is necessary to consider SAEs and the components that surround it as one dynamic model in order to understand its operation in space and time, the constant flow of interactions among the components inside and outside of the system, which are tied together and in constant re-organization.

This analytical model does not agree with dialectic philosophy that promotes human effort as the dominant element in nature and human society, and does not consider subjective rationality for judging actions and human modes of living (Chávez, 2004). Thus, we accept as valid the criteria of the investigator in generating abstractions of reality and explaining the phenomenon observed during an investigation. Even when conflicts or contradictions among social classes may not be addressed, the high functional-structural load of this model cannot rule out the existence of eclectic links among the principal controversial schools of thought.

\section{Theoretical Premises}

Under the premise that the search for complex knowledge is a product of continuous learning (positivist and dialectical), one of the bases of the model is complexity theory proposed by the humanist Edgar Morin (1988). This theory is characterized as incorporating awareness of the complexity of reality arising from the interaction among biological, physical, social, economic and historic elements, and of the rise of stochastic events based not only on the development of an investigation but also in the process of learning and action among the subjects (producers, investigators, etc.) during project development.

Complexity theory analyzes reality as a web of events, actions, interactions, feedback and decisions that constitute our surroundings. It is also concerned with the study of "systems" as a consequence of object perception, as phenomena and specific processes, understanding "systems" as those that have characteristics, qualities or particularities (Herrscher, 2003) such as component heterogeneity (multiple and diverse in nature), nonlinear interactions, multiple interactions between them, their multidimensional and multi-referential nature, and that they usually present numerous variables for measurement. This theory considers that under apparent static or simplicity of the situation, the true dynamics of such processes and the interactions among their parts are often hidden (Morin, 1988).

Another of the theories based on this model is the structural-functionalist theory, which is the origin of systems theory, and establishes that the elements of a determined social structure are interdependent. Thus, variation in some of these elements will impact others. The theory conceptualizes systems as orderly arrays of elements, static or dynamic, interdependent and open to variables that can modify them (thus agreeing with complexity theory). The systems maintain borders with other systems and function in the assembly of processes among them. According to Parsons' systemic theory, the action of an individual is oriented to achieve an end within a situational context (Sevilla, 2006). On the other hand, systems theory is intimately linked to cybernetics, a theory of communication and control, which also is known as the science of governance and systems regulation (Herrscher, 2008). Therefore, from the structural-functionalist point of view, the producer (the decision-maker, according to cybernetics theory) will always try to maintain a status according to their location and role in society, to which public and private institutions, associations, and others, also belong.

Given this perspective, the form of management that a producer applies on the SAEs will depend on their cultural background, the products of the interrelations that are maintained with the social sector to which they belong, and the influence on them from other organizations in which they participate (institutions of investigation, associations, etc.). All these determine the health and productivity of the agroecosystems having sugarcane production. Using dialectic philosophy mixed carefully with theoretical structural-funcionalist and functional-structuralist models, there is evidence of a small step toward the construction of eclectic complexity theory. The status or role of humans in society and within the environment will depend on the process of continuous learning. Throughout this process, each individual acquires a set of capacities, knowledge, experiences and habits from their actions and interactions with their external environment (society, environment, etc.). As mentioned previously, there is progressive conformance in the development of the personality of the subject (producer, investigator, etc.) and with it, a continuous change in the system. The interactions among the previously mentioned phenomena result in a complex problem, where physical-biological contexts, production, technology, social organization, economics and politics are involved. Situations characterized by the confluence 
of multiple processes whose interrelations constitute the structure of a system that functions as if it were completely organized, are called "complex systems" (García, 2000).

The consequence of employing a systemic perspective in the analytical model of phenomenological reality, hermeneutical and dialectic, is what makes it possible to see the agroecosystem not as a system that has an end predetermined by someone as it is traditionally stated, but as that which has diverse ends and functions for the processes of interest to the producers and associations, resulting in interpretive variety. This diversity of interpretation will be conditioned by the interests and values possessed by those involved (producers, associations, etc.), whose key element is common interest centered on the need to attend to complex problems (Herrscher, 2003) to achieve agroecosystem sustainability.

\section{Conceptual Bases and Model Methodologies}

The SAE analytical model (Figure 1) is an eclectically creative attempt at joining select elements of dialectic philosophy with historic materialism theory to establish categories that help to identify the production system (producer), the associations (social relations of production) and private and public institutions for investigation (legal, political and ideological), whose synergy culminates in the immediate production of what society demands (Parra et al., 1984). However, the model avoids the historical materialistic conception (unfair and oppressive) where the grouping of people into social classes is based on the production and economy of the State. This has impeded the working-class in participating in product industrialization and the economic profit-sharing generated by their efforts.

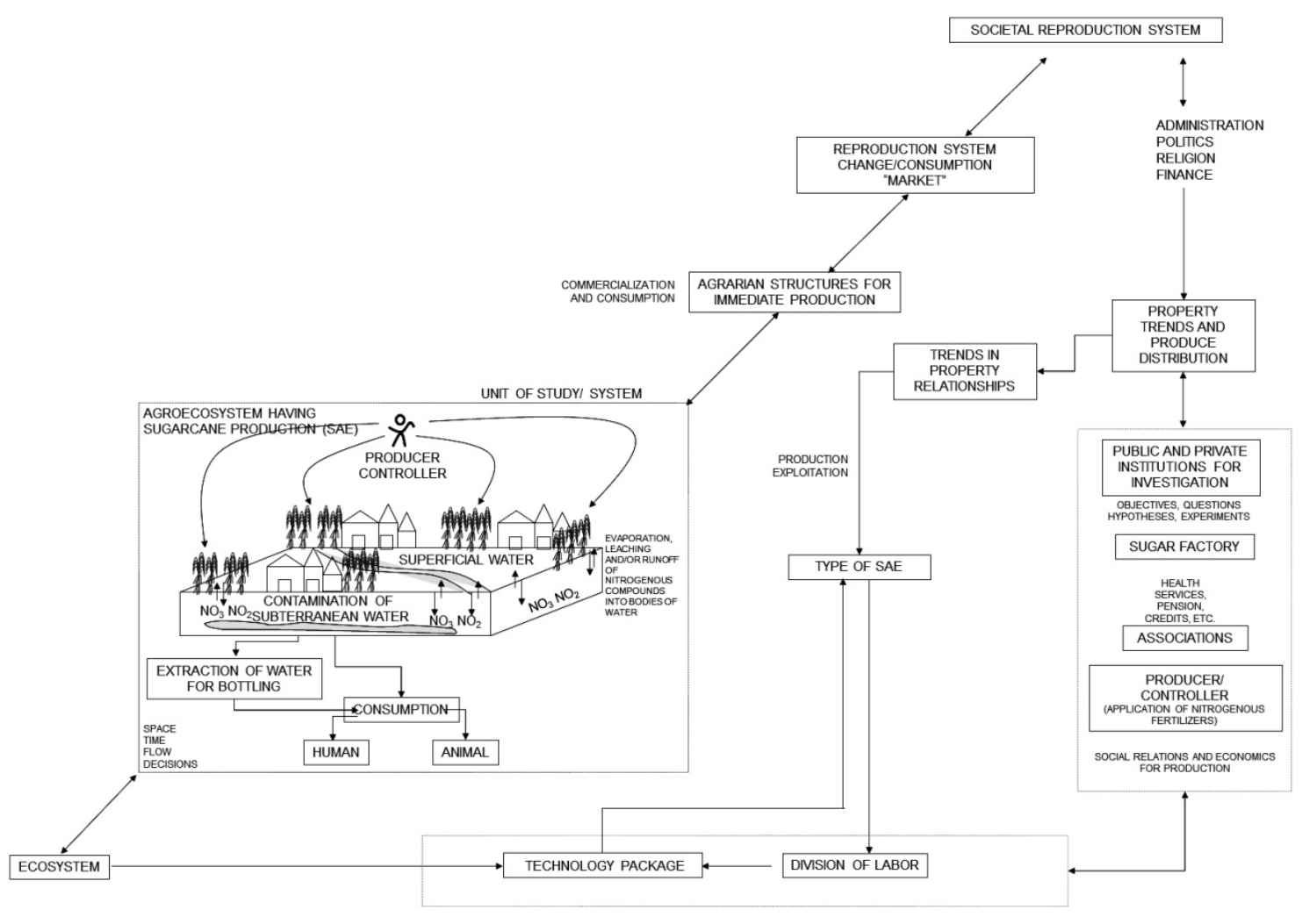

Figure 1. Theoretical-conceptual model for the analysis of sugarcane agroecosystems (SAEs) and the importance of the effect of nitrogenous fertilizers on the environment and human health (modified from Galaviz et al., 2010)

Even when traditionally the adequate procedure to undertake any problem of investigation in its totality is the dialectic method, another starting point in the constant search for knowledge is systemic thought. This method employs perception of the real world in terms of totalities for analysis and comprehension, as opposed to the scientific method that only perceives parts, but in an incoherent manner. 
Therefore, this analytical model employs a systemic focus that considers objects of study to be assemblies of interdependent parts. It has these characteristics because its structure and function depend on the environment surrounding it, which determines the existence of relationships among the diverse components, systems and subsystems (Lilienfeld, 1984) in a conflictive and occasionally contradictory manner. Methodologically, the model attempts to interpret phenomena by integrating the theoretically contrary schools of thought, as in this case. A similar focus to this model is that utilized by Trebuil (1990), who inserted a structural-functionalist element into a dialectical model (i.e., the agroecosystem), without which the resultant model would have lost explanatory capacity. Yet, a greater richness in the analysis of the system can be achieved even when agreements with the model of this author do not occur in all situations. However, in the SAE analytical model, elements of complex thought have been inserted to provide explanations with greater global holism. Our model integrates elements that impact each of the phenomena arising in different hierarchical levels (Trebuil, 1990), without the hierarchical term necessarily denoting a power relationship, but instead a purely qualifying subordination (Herrscher, 2003). As such, all existing systems can be observed with a unified reality of objects, whose recursivity is presented as different degrees of complexity in ascending or descending form (Johansen, 1993). This methodology is also dynamic because it recognizes that agroecological evolution is a function of socio-economic processes that are undertaken with an interdisciplinary focus (Trebuil, 1990).

The nature of this analytical model involves inductive and deductive methodological tools to obtain a diagnosis much closer to the reality for SAEs. These tools are generally associated with quantitative and qualitative investigation, respectively. Quantitative approaches are used to collect and analyze data, such as the concentrations of $\mathrm{NO}_{3}$ and $\mathrm{NO}_{2}$ in water. Qualitative approaches are used for narrative registrations of phenomena that are studied using participant observation and semi-structured interviews, such as interviews of key informants for the establishment of investigation criteria. As such, quantitative methodologies study the association or relation between numerical variables, while qualitative methods do so in situational, functional, and structural contexts (Pita \& Pértegas, 2002). In our model, as in others that have been proposed for the analysis of agricultural development, human beings are seen as "decision-makers" in their role as farmers or as administrative board members for rural or business organizations. In this sense, the "controller" is the main protagonist that receives the stimuli (positive or negative) from outside and inside their production unit. Thus, they process their own information on their cultural backgrounds and sociological characteristics. Based on these processes, the controllers make their own decisions about what fertilizer to use, how much, and when and how to apply it, thus determining management rationality (Martínez, Gallardo, Bustillo, \& Pérez, 2010).

The establishment of the hierarchical borders of this analytical model is a modification of the dialectic-Marxist proposal of Parra et al. (1984) who indicated that from the existence of an ecosystem that is transformed or modified by the action of a controller, we can arrive at a global socio-economic level. Upon incorporating the elements obtained from the functionalist-structural conceptualization of an agrarian system (Trebuil, 1990) it is possible to identify an agroecosystem, along with some variables and relations among the elements integrated into an SAE analytical model, for study. The model possesses categories and socio-production interactions ordered under the same hierarchical classification. Thus, this analytical model employs elements of different theoretical-philosophical schools of thought that help to better explain reality, as opposed to the employment of them separately. The criteria proposed here provide evidence for the beginning of a small part of the construction of complexity in its theoretical approaches.

\section{Case Study}

In Mexico, sugarcane cultivation covers 812,000 hectares, from which approximately 5 million tons of sugar are produced annually. Of this production, $38.4 \%$ is from 22 sugar refineries located in the state of Veracruz, contributing to domestic market supply. The sugar industry in Mexico is one of the most important in the country with projections for growth and having great social, political, and economic force, which benefits 12 million Mexicans (Calatayud \& Jácome, 2007; UNC, 2010). Despite the importance of this crop in Mexico, and particularly in the state of Veracruz, the existing knowledge has not been transferred appropriately to sugarcane producers in relation to the management of nitrogenous fertilizers and water according to the different types of soil and precipitation levels, in order to improve the productivity of these agroecosystems and to avoid environmental impact and risks to public health (Figure 2).

Hoffmann and Velázquez (1993) affirmed that the "sugarcane system" in Veracruz is composed of a rural population that has a low education level, although professionals and technical help also are integrated in smaller proportions. Under these conditions, the plan for traditional production does not alter the conception of "what should be done" or "what has always been done", as occurs in most rural societies established within a given territory. However, the sociocultural and economic position of a producer imposes limitations depending on their 
flexibilities and perceptions. This causes low management efficiency of the crop with negative impacts to the environment.

Until 2009 no investigations had been performed on the adequate management of nitrogenous fertilizers within the Irrigation Zone of La Antigua (I-1), in the state of Veracruz. Based on a study carried out by Moreno et al. (2011) inside this same zone, they proposed a nitrogen dose of $150 \mathrm{~kg} \mathrm{ha}^{-1}$ provided as three doses of $50 \mathrm{~kg} \mathrm{ha}^{-1}$ per application, yielding $126 \mathrm{t} \mathrm{ha}^{-1}$ of sugar cane. Thus, a single dose of fertilizer is an obsolete recommendation (Landeros, Castañeda, Lango, Moreno, \& Palomares, 2007; Calatayud \& Jácome, 2007). It has also been shown that areas with ranching or intensive farming also contribute to the deterioration of aquifer water quality, leading to potential threats to public health, ranching and aquacultural activities, and the health of agroecosystems in general (Dukes \& Evans, 2006; Larios, 2009; Galaviz et al., 2010, 2011; Landeros et al., 2012).

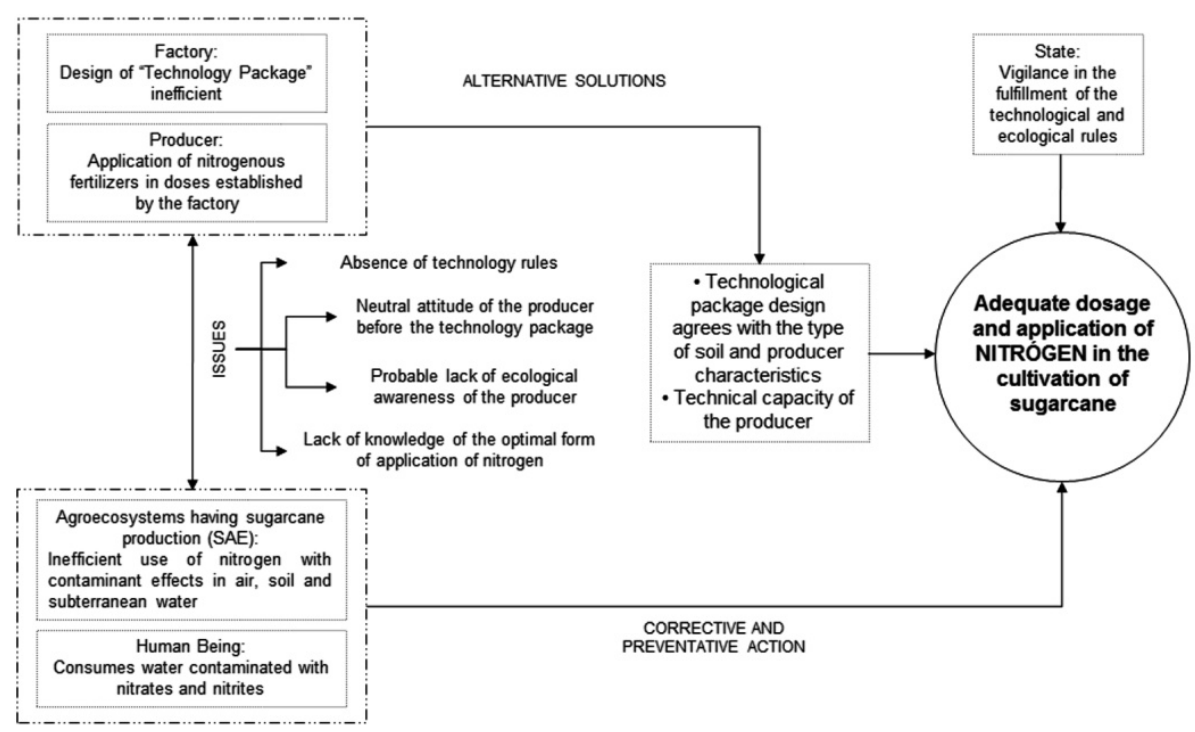

Figure 2. Conceptual model of the inefficient management of nitrogenous fertilizers in sugarcane agroecosystems and alternative solutions in the central zone of the Gulf of Mexico

According to Galaviz (2010), the technology for the allocation of fertilizer doses containing N, P and K has been developed without considering issues such as different types of soil characteristics, variations in climatic conditions, quality of irrigation water, among others. All this, including the lack of technology transfer and technical training to producers, has led to deficient management of nitrogenous fertilizers in sugarcane cultivation. The acceptance of technological improvements by producers was not a denial of an ecological awareness, but was due to the lack of information on the long-term effects of the use of a technology that was not environmentally friendly, and to the socio-economic benefits provided to the sugarcane plantation owners, although it did not significantly improve their quality of life. This results in the deterioration of agroecosystems having sugarcane cultivation through reduced biodiversity, impoverishment of soils, low yields and contamination of groundwater with nitrates (Galaviz et al., 2010), which has resulted in public health problems as a consequence. In Mexico, models exist for technology transfer including diffusionist, technological packages, producer-researcher method, agronomist-producer, and the Chilean model (Mata, 1993). These methods have been developed and applied in the training of sugarcane producers. Although these models are not all successful, the mixing of some of their elements is more promising for the production of a more environmentally friendly model that also satisfies the needs of each producer, complies with regional demands and offers, and provides the technological training that the sugarcane plantation owners require. It is possible to structure a model that promotes communication between producers and private and public institutions for the joint design of technology and services that include training and monitoring, according to the production level and needs of each grower.

It is important to mention that the division of total nitrogenous fertilizer application into smaller doses applied throughout the cultivation cycle as proposed by Moreno et al. (2011) represents a strategic alternative to improve sugarcane performance and to maintain the health of the agroecosystems having sugarcane cultivation and of 
man. The design of a specific technology that responds to the cultivation needs and benefits sugarcane producers will make it possible to include sustainability in a plan of social equity (Conway, 1985).

\section{Final Comments}

According to Conway (1985), an agroecosystem is an ecosystem modified by man, who acts as an intermediate to provide labor and determine management. Although defining it seems simple, the complexity of the conceptualization of an agroecosystem increases with the inclusion of economic, cultural, politico-social, and biological aspects and their interactions. Describing an agroecosystem can turn out to be very complex, especially when trying to refer to all possible outputs of all interactions between man and the environment.

On the other hand, Martínez et al. (2010) defined an agroecosystem as a conceptual model based on the minimum level of control that man has on the environment or as a consequence of a complex system that enables an integrated vision of the universe. In other words, an agroecosystem is an optimal unit for the study of agriculture and for its own transformation. It experiences environmental, economic, cultural, and political interferences, from private and public institutions that contribute, chiefly, to food production, commodities and environmental services that society demands. In this way, according to Martínez et al. (2010), the objectives for the agroecosystem depend on the type of decision-maker regulating it, on the resources produced in it, and on its interrelation with the environment.

The eclectic nature of this model originates from its ability to take up and unite conceptual elements belonging to heterogeneous schools of thought, selectively analyze them in a conciliatory form for convergence, and propose a form for interpreting reality for a specific place and time. The conceptualization of the agroecosystem is limited by the knowledge of the observer, which expands or narrows their perception and identification of the universe of synergistic and recursive elements that form and surround it. These elements, upon interacting among themselves at different levels, produce a series of effects that for some are imperceptible. The lack or loss of observer perception is a result of the lack of knowledge that impedes recognizing the changes that the ecosystem has experienced when it has been modified by man.

\section{Acknowledgements}

Thanks to Instituto Tecnológico de Boca del Río for the financial support, the Colegio of Postgraduados Campus Veracruz ("LPI8 Impacto y Mitigación del Cambio Climático") especially to Dr. Juan Pablo Martínez Dávila for his contribution in the knowledge of this topics, and to Ing. Juan Manuel Hernández Pérez in the assistance for the preparation of figures.

\section{References}

Calatayud, L., \& Jácome, S. (2007). El CEVIM* suma fuerzas para diversificar la industria cañera. Centro Virtual de Investigación Multidisciplinaria. Retrieved from http://www.uv.mx/cienciahombre/revistae/vol16num1/articulos/cevim/cevim.htm

Chávez, C. P. (2004). Historia de las doctrinas filosóficas (3th ed.). México: Pearson Educación.

Conway, G. R. (1985). Agroecosystem Analysis. Journal of Agricultural Administration, 20, 31-55. http://dx.doi.org/10.1016/0309-586X(85)90064-0

Dukes, M. D., \& Evans, R. O. (2006). Impact of agriculture on water quality in the North Carolina Middle Coastal Plain. Journal Irrigation and Drainage Engineering, 132(3), 250-262. http://dx.doi.org/10.1061/(ASCE)0733-9437(2006)132:3(250)

Galaviz, V. I. (2010). Contaminación del agua con nitratos y nitritos y su impacto en la salud pública en la zona de influencia del módulo de riego (I-1) La Antigua, Ver. México. Colegio de Posgraduados, Campus

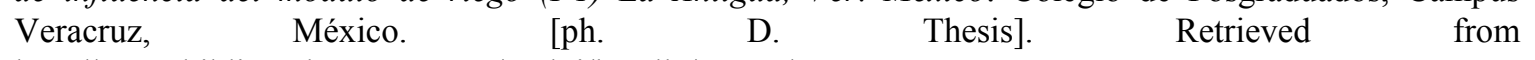
http://www.biblio.colpos.mx:8080/xmlui/handle/10521/429

Galaviz, V. I., Landeros, S. C., Castañeda, C. M., Martínez, D. J., Pérez, V. A., Nikolskii, G. I., \& Lango, R. F. (2010). Agricultural contamination of subterranean water with nitrates and nitrites: An environmental and public health problem. Journal of Agricultural Science, 2(2), 17-30.

Galaviz, V. I., Landeros, S. C., Castañeda, C. M., Lango, R. F., Martínez, D. J., Pérez, V. A., \& Nikolskii, G. I. (2011). Presence of nitrates and nitrites in water for human consumption and their impact on public health in sugarcane producing areas. Tropical and Subtropical Agroecosystems, 13, 381-388. 
García, R. (2000). Conceptos básicos para el estudio de sistemas complejos, In E. Leff (Ed.), Los problemas del conocimiento y la perspectiva ambiental del desarrollo (2a Ed.) (pp. 381-413). México D. F.: México Siglo XXI.

Herrscher, G. E. (2003). Pensamiento Sistémico. Caminar el cambio o cambiar el camino. México D.F.: Granica México S. A. de C. V.

Herrscher, G. E. (2008). Planeamiento sistémico. Un enfoque estratégico en la turbulencia. (1 ${ }^{\mathrm{a}}$ ed.). Buenos Aires, Argentina: Granica S. A. de C. V.

Hoffmann, O., \& Velázquez, E. (1993). Sistema de Producción e Historia: Una Propuesta para el análisis regional (Centro Veracruz, México). In H. Navarro, J. P. Colin, \& P. Milleville (Eds.), Sistemas de producción y desarrollo agrícola (pp. 11-128). México D. F.: ORSTOM-CONACYT-CP.

Hurtado, B. J. (2000). Metodología de la Investigación Holística. (3a Ed). Caracas: Sypal.

Johansen, O. (1993). Introducción a la teoría general de sistemas. México D. F.: Limusa.

Landeros, S. C., Castañeda Chávez, M. R., Lango Reynoso, F., Moreno Seceña, J. C., \& Palomarez García, M. (2007). Contaminación del agua por nitrógeno causada por la agricultura en zonas cañeras de Veracruz, México. In IX Simposio internacional y IV Congreso nacional de agricultura sostenible. Agricultura sostenible: obligada ante los retos (1a ed.) (pp. 261-269). Veracruz, México: SOMAS \& UNACH. ISBN 978-607-75-33-32-0, Vol. 4.

Landeros, S. C., Lango, R. F., Castañeda, C. M., Galaviz, V. I., Nikolskii, G. I., Palomarez, G. M., ... Mínguez, R. M. (2012). Assessment of water pollution in different aquatic systems: aquifers, aquatic farms on the Jamapa river, and coastal lagoons of Mexico. Journal of Agricultural Science, 4(7), 186-196. http://dx.doi.org/10.5539/jas.v4n7p186

Larios, O. L. (2009). Contaminación del agua con nitratos. Significación sanitaria. Revista Archivo Médico de Camagüey, 13, 2.

Lilienfeld, R. (1984). Teoría de Sistemas. México D. F.: Trillas.

Martínez, D. J. P., Gallardo, L. F., Bustillo, G. L., \& Pérez, V. A. (2010). El agroecosistema, unidad de estudio y transformación de la diversidad agrícola en Veracruz (pp. 1071-1080). México, D. F.: CONABIO.

Mata, G. B. (1993). Algunos modelos para la capacitación y transferencia de tecnología. In Memorias del Simposio Nacional para la Capacitación y Desarrollo Tecnológico en el campo Cañero (pp. 482-486). Xalapa, Veracruz.

Moreno, S. J., Landeros, S. C., Pérez, V. A., Castañeda, C. M., López, C. C., \& Palacios, V. O. (2011). Nitrogen management in sugarcane and its influence on yield, profitability and leaching losses. Tropical and Subtropical Agroecosystems, 13(3), 373-379.

Morin, E. (1988). Introducción al pensamiento complejo (2a ed.). México, D. F.: Gedisa.

Parra, V. M. R., Perales, R. M., Inzunza, M. F., Solano, S. C., Hernández, X. E., \& Santos, O. A. (1984). La regionalización socioeconómica. Una perspectiva agronómica. Geografía Agrícola, 5(6), 24-34.

Pérez-Tamayo, R. (1998). Existe el método científico?: Historia y Realidad. (2a ed.). USA: Fondo De Cultura Económica.

Pita, F. S., \& Pértegas, D. S. (2002). Investigación cualitativa y cuantitativa. Cad Aten Primaria, 9, 6-78.

Sevilla, E. (2006). De la sociología rural a la agroecología. Barcelona, España: Icaria.

Trebuil, G. (1990). Principles and steps of the method of diagnosis on agrarian systems: A case study from Sathing Phra area Southern Thailand. Agroecosystem analysis / diagnosis on agrarian systems. In Farming systems research and development in Thailand Part 1 (pp. 29-64). Thailand: Prince of Songkla University.

UNC. (2010). Estadísticas de la Agroindustria de la Caña de Azúcar 2000-2009. Unión Nacional de Cañeros, A.C.-CNPR Comité Ejecutivo Nacional 2007-2010. Retrieved from http://www.caneros.org.mx/estadisticas.htm 